Bulletin d'Histoire Contemporaine de l'Espagne

$50 \mid 2016$

Les intellectuels en Espagne, de la dictature à la démocratie (1939-1986)

\title{
Carmen de Burgos, Gloriosa vida y desdichada muerte de Riego. (Un crimen de los Borbones)
}

\section{Gérard Dufour}

\section{OpenEdition}

\section{Journals}

Edición electrónica

URL: http://journals.openedition.org/bhce/917

DOI: 10.4000/bhce. 917

ISSN: 1968-3723

\section{Editor}

Presses Universitaires de Provence

\section{Edición impresa}

Fecha de publicación: 1 diciembre 2016

Paginación: 287-288

ISSN: 0987-4135

\section{Referencia electrónica}

Gérard Dufour, "Carmen de Burgos, Gloriosa vida y desdichada muerte de Riego. (Un crimen de los Borbones) », Bulletin d'Histoire Contemporaine de l'Espagne [En línea], 50 | 2016, Publicado el 09 octubre 2018, consultado el 24 septiembre 2020. URL : http://journals.openedition.org/bhce/917 ; DOI https://doi.org/10.4000/bhce.917 
Alicante en 2008). Y aunque la tonalidad general de esta poesía inglesa de la Guerra de la Independencia manifiesta un odio generalizado a Napoleón y la exaltación de cuantos luchaban por su derrota, matices importantes como las que ofrece Byron son uno de los atractivos más significativos del libro.

No estamos en condiciones de detectar errores eventuales en las traducciones. En cambio, sí que podemos afirmar que los Profesores Laspra y Coletes han sabido, gracias en particular, como lo pretendieron (p. 29), al ritmo utilizado, presentarnos un texto que no «huela» a traducción, lo cual-suponemos- debió costarles un esfuerzo importante, pero que merecía la pena. También cabe valorar las ilustraciones, cuidadosamente elegidas y casi todas poco conocidas, que habían de ser más que una mera ornamentación. Sin embargo, la calidad de reproducción de las ilustraciones (exclusivamente en blanco y negro) no está a la altura de un libro de esta categoría. Demasiado oscuras y de tamaño exageradamente reducido, en varios casos no permiten al lector percatarse de su interés. Pero, esto no es responsabilidad de los autores, sino de la editorial que, por cierto, realizó una impresión muy cuidada, con contadísimas erratas. El único error (sin duda mera errata) de los Profesores Laspra y Coletes consiste en la fecha de la primera abdicación de Napoleón que no tuvo lugar el 14 de abril de 1814 (p. 200), sino el 4 (abdicación bajo presión de los mariscales), con confirmación el 6 de abril de 1814 (abdicación sin condiciones).

Esperamos pues la continuación de la publicación de los resultados del proyecto OLE'11, para los cuales esta obra tiene que servir no solo de precedente, sino de modelo.

Aix-Marseille Université, CNRS, UMR 7303 TELEMME

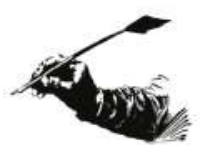

\section{Carmen de BURGOS}

Gloriosa vida y desdichada muerte de Riego. (Un crimen de los Borbones). Estudio introductorio de Manuel Moreno Alonso, Sevilla, Centro de Estudios andaluces, Editorial Renacimiento, 2013.

Apenas se quemaron los últimos cartuchos de las conmemoraciones del bicentenario de los acontecimientos de 1808-1813, se oyen los tambores de guerra de lo que va a ser otra gran campaña historiográfica y editorial: la que supondrá en 2020 otro bicentenario, el del restablecimiento de régimen constitucional en España y principio del Trienio liberal.

Especializada en la reedición de textos antiguos, la editorial sevillana Renacimiento abrió el fuego con la reimpresión de la obra Gloriosa vida y desdichada muerte de Riego. (Un crimen de los Borbones) publicada en 1931 por Carmen de Burgos. Con semejante título, más propio de un romance de ciegos que de un estudio científico, la autora no ocultaba ni su propósito hagiográfico ni su odio de los Borbones. Con lo cual, resulta bastante gracioso constatar que, en la versión que hoy día se pone a la venta, el subtítulo ofensivo a la dinastía de los Borbones ha sido suprimido en la solapa y en el cuerpo del texto (p. 155), y tan solo aparece en la portada. Sin embargo, pese a su declarada y reivindicada parcialidad, la autora realizó, en su época, un trabajo serio, a base de documentos de archivos, aunque, por supuesto resulta hoy superado (y mucho) por publicaciones entre las cuales destacan las de 
Alberto Gil Novales. Así que el interés de esta reedición no reside en lo que aporta respecto a Riego, sino en lo que nos revela de la importancia del héroe de las Cabezas de San Juan en la formación de la ideología republicana por los años de 1930.

Para el editor científico de esta reimpresión, Manuel Moreno Alonso, la obra de Carmen de Burgos, Gloriosa vida y desdichada muerte de Riego. (Un crimen de los Borbones) constituye un ejemplo perfecto del proceso de mitificación al que los «progresistas» (desde los liberales hasta los republicanos) sometieron al que logró hacer jurar la Constitución de 1812 a Fernando VII. Así que en su largo «estudio introductorio» (146 páginas) no se contentó con la consabida presentación de la autora y de las condiciones de redacción y publicación del libro, que despachó todo en un poco más de ocho páginas. Y dicho sea de paso, pese a su rapidez, su presentación biográfica de Carmen de Burgos, alias Colombine, prolífica polígrafa, periodista y primera corresponsal femenina de guerra en 1909, persuade al lector de que ella no solo fue una mujer libre (compañera sentimental de Ramón Gómez de la Serna), de arraigadas convicciones de izquierda, sino sobre todo excepcional. Pero el verdadero interés de Manuel Moreno Alonso no está en la autora, sino en el mito de Riego que contribuyó en propagar, y que el se propone desmontar.

Así que, rapidísimamente, el «estudio introductorio» se convierte en una revisión y refutación, paso a paso, de la figura del «inmortal Riego». Apoyándose en su notable erudición y magnífico conocimiento del período, el «editor científico» nos ofrece pues un retrato despiadado de un Riego indigno, según él, de la admiración que se le tributa.

El «estudio introductorio» de Manuel Moreno Alonso resulta pues ser la antitesis del libro que presenta. Según la consabida fórmula, al lector le tocará formarse su propia idea. Pero, no le resultará nada fácil. Las numerosísimas críticas a Riego que cita Manuel Moreno Alonso se apoyan todas en el testimonio de coetáneos del héroe de las Cabezas de San Juan. Pero abundan también entusiastas manifestaciones de apoyo y de admiración a su persona que el denigrador de Colombine no tomó en consideración.

Manuel Moreno Alonso, en su estudio más crítico que introductorio quiso ser iconoclasta: lo ha conseguido. Con ello, se granjeará la inquina de cuantos ven en Riego todo un héroe, un mártir de la libertad. ¿Logrará, en cambio, como se lo propone, «desmitificar» esta gloria nacional? De momento, la visión que nos propone no pasa de ser un mero contrapunto y es tan parcial (aunque de sentido opuesto) como la que refuta. Pero no descartamos que el propio Moreno matice en una obra próxima el retrato tan negro de Riego que nos ofrece con motivo de esta reedición del libro de Carmen de Burgos.

Así que no solo se oyen los tambores de guerra de la próxima campaña historiográfica y editorial que nos reserva la conmemoración del bicentenario del restablecimiento del régimen constitucional en 2020. Ya empezaron los enfrentamientos. Y no por una escaramuza, sino por un tiro de artillería pesada.

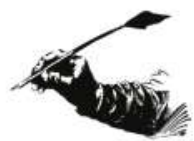

